\title{
Effect of Nickel on the Microstructure and Mechanical Property of Die-cast Al-Mg-Si-Mn Alloy
}

\author{
Hailin Yang ${ }^{1}$, Douglas Watson ${ }^{1,2}$, Yun Wang ${ }^{1}$, Shouxun $\mathrm{Ji}^{1}{ }^{1}$, \\ 1- Brunel Centre for Advanced Solidification Technology (BCAST), Brunel University London, Uxbridge, Middlesex, UB8 3PH, \\ United Kingdom \\ 2- Engineering Centre, Jaguar Cars Ltd, Abbey Road, Coventry, CV34 4LF, United Kingdom \\ * Email address: shouxun.ji@brunel.ac.uk Tel.: +44 1895 266663; Fax +44 1895269758.
}

\begin{abstract}
The effect of nickel on the microstructure and mechanical properties of a die-cast Al-Mg-Si-Mn alloy has been investigated. The results show that the presence of $\mathrm{Ni}$ in the alloy promotes the formation of Ni-rich intermetallics. These occur consistently during solidification in the die-cast Al-Mg-Si-Mn alloy across different levels of Ni content. The Ni-rich intermetallics exhibit dendritic morphology during the primary solidification and lamellar morphology during the eutectic solidification stage. Ni was found to be always associated with iron, forming $\mathrm{AlFeMnSiNi}$ intermetallics and no $\mathrm{Al}_{3} \mathrm{Ni}$ intermetallic was observed when $\mathrm{Ni}$ concentrations were up to $2.06 \mathrm{wt} \%$ in the alloy. Although with different morphologies, the Ni-rich intermetallics were identified as the same $\mathrm{AlFeMnSiNi}$ phase bearing a typical composition of $\mathrm{Al}_{[100-140]}(\mathrm{Fe}, \mathrm{Mn})_{[2-7]} \mathrm{SiNi}_{[4-9]}$. With increasing Ni content, the spacing of the $\alpha-\mathrm{Al}-\mathrm{Mg}_{2} \mathrm{Si}$ eutectic phase was enlarged in the Al-Mg-Si-Mn alloy. The addition of Ni to the alloy resulted in a slight increase in the yield strength, but a significant decrease in the elongation. The ultimate tensile strength (UTS) increased slightly from 300 $\mathrm{MPa}$ to $320 \mathrm{MPa}$ when a small amount (e.g., $0.16 \mathrm{wt}$. \%) of $\mathrm{Ni}$ was added to the alloy, but further increase of the Ni content resulted in a decrease of the UTS.
\end{abstract}

Keywords: Aluminium alloy; microstructural evolution; mechanical properties; Ni-rich compounds; high pressure die casting; CALPHAD modelling

\section{Introduction}

In the manufacture of fuel efficient transport systems, weight reduction through the use of lightweight materials remains a very successful and simple means of improving fuel economy and reducing harmful emissions. Increases in aluminium alloys usage for automotive applications provide significant opportunities for weight reduction and therefore real scope to achieve environmental goals, when compared to a conventional steel-based vehicle [1,2]. A $100 \mathrm{~kg}$ reduction in car weight leads to a saving of $10 \mathrm{~g} \mathrm{CO}_{2}$ per kilometre [3]. Aluminium's weight to strength ratio and its high recyclability potential has resulted in a number of aluminium intensive vehicles being released by major automotive manufacturers. This light-weighting strategy has resulted in a decrease of $\mathrm{CO}_{2}$ produced during the vehicle use phase and also in the manufacturing stage by reducing the use primary aluminium through utilising end-of-life vehicles (ELVs) metal scrap recycling [4,5]. Up to 75\% of aluminium recycled in Europe has been used for applications in transportation [6]. The re-use of recycled metal scraps is an important factor for the closed-loop material cycles to support circular economies in accordance with ecological principles [7,8]. Consequently, it is important and essential to understand more about the recycling of aluminium alloys.

In recycling aluminium alloys, the unchecked accumulation of impurities will result in the solute concentrations of these elements exceeding the limitation of the registered specification, this restricts the application of recycled aluminium alloys in a closed loop cycle $[9,10]$. The list of problematic impurities varies from one alloy to the other. Generally, the impurity elements include but are not limited to $\mathrm{Si}, \mathrm{Mg}, \mathrm{Ni}, \mathrm{Zn}, \mathrm{Pb}, \mathrm{Cr}, \mathrm{Fe}, \mathrm{Cu}, \mathrm{V}$ and $\mathrm{Mn}$ in different aluminium alloys [11,12]. The effect of impurities on the microstructure and mechanical properties has been one of the major topics of many publications for the application of recycled aluminium alloys [12,13]. However, there is still a lack of understanding of the roles of some impurities such as nickel in aluminium alloys.

Nickel is defined as an impurity in many commercial aluminium alloys with a limitation of $0.2 \mathrm{wt} . \%$, although it has been used as an alloying element up to a level of $2.5 \mathrm{wt} . \%$ in some commercial aluminium alloys, which can be found in both wrought and casting alloys $[14,15]$. In alloying of aluminium nickel has been recognised as a strongly partitioning and slow-diffusing element [16]. Nickel is almost insoluble in aluminium; with solubility being about 0.05 wt. $\%$ at $640{ }^{\circ} \mathrm{C}$ and less than 0.005 wt. $\%$ at $450{ }^{\circ} \mathrm{C}$ [17]. In the Al-Ni binary alloy, the addition of nickel up to $2 \mathrm{wt} . \%$ gives an increase in the strength of aluminium, but a decrease in ductility [18]. Similar results were found in multicomponent aluminium systems and the aluminium matrix is unlikely to contain Ni levels above the equilibrium solubility. It was reported that $\mathrm{Ni}$ was mainly associated with iron in the form of AlFeSi intermetallics at low levels and in the form of $\mathrm{Al}_{3} \mathrm{Ni}$ intermetallics at higher concentrations, such as in an $\mathrm{Al}-\mathrm{Mg}-\mathrm{Si}$ wrought alloy containing $1.4 \mathrm{wt} . \% \mathrm{Ni}$ [18]. A recent investigation [16] has also shown that Ni additions up to 0.05 wt.\% did not have an obvious influence on the phase constituents of AA6063 alloy. A significant influence on the microstructure were observed in the as-cast condition of AA3102 alloy when Ni content was 0.05 wt.\%. For A356 alloy, Ni additions up to 0.02 wt.\% did not a have significant influence on the as-cast microstructure, but a new phase was formed when the Ni addition was increased to $0.05 \mathrm{wt} . \%$. These intermetallics have been found to be AlFeMgSi and AlFeSi phases in the as-cast and heat-treated A356 alloy [18, 19]. Therefore, it is important to verify whether $\mathrm{Ni}$ is an impurity or a useful alloying element in aluminium alloys. Recently, an Al$\mathrm{Mg}-\mathrm{Si}-\mathrm{Mn}$ alloy that can provide improved ductility has been investigated for thin-wall structural application in car body structures produced through high pressure die castings [20,21]. It has been found that the improved ductility can only be achieved with tight control of impurities levels. Iron has been identified as a detrimental element for the mechanical properties and needs to be minimised during application of the recycled alloys [22,23]. However, it is still unclear for the effect of other common elements including $\mathrm{Ni}$. In order to enhance the understanding towards the microstructural evolution and mechanical properties, the study of the Ni effect becomes essential in the alloy if it is to satisfy the required mechanical properties in application. This is 
J Mater Sci (2014) 49:8412-8422

practically important for the materials recyclability where the various elements are interacting within the alloy during the industrial melting, casting and solidification process.

The present study investigated the effect of $\mathrm{Ni}$ on the morphology, size and distribution of Ni-rich compounds in the Al-Mg-SiMn alloy, produced by a high pressure die casting process. The mechanical properties, such as yield strength, ultimate tensile strength (UTS) and elongation were assessed for the die-cast samples with different Ni contents. To enhance understanding, the role of $\mathrm{Ni}$ in the alloy chemistry was investigated by CALPHAD modelling of the multi-component $\mathrm{Al}-\mathrm{Mg}-\mathrm{Si}-\mathrm{Mn}$ system. The discussions focused on the phase formation of different Ni-rich intermetallic phases and the relationship between the Ni-rich compounds and the mechanical properties of the die-cast Al-Mg-Si-Mn alloy.

\section{Experimental}

The Al-Mg-Si-Mn alloy was supplied by an industrial alloy manufacturer to a specified composition. The alloy was received in the form of ingots. During experiments, the alloy was remelted in a crucible and the different Ni contents were added by using Al$10 \mathrm{wt} . \% \mathrm{Ni}$ master alloy. The melt was degassed using $\mathrm{N}_{2}$ in a commercial rotary degasser at $500 \mathrm{rpm}$ for 3 minutes before casting a sample for composition analysis. The composition was analysed using an optical mass spectroscopy on a cross section of a $\phi 40 \times 60 \mathrm{~mm}$ cylindrical casting sample, in which at least five spark analyses were performed and the average value was taken as the chemical composition of the alloy. The measured compositions of the alloys containing $0.005 \mathrm{wt} . \%$ to $2.06 \mathrm{wt} . \% \mathrm{Ni}$ are shown in Table 1.

After composition analysis and skimming, the alloy melt was manually ladled into the shot sleeve of a 4500kN HPDC machine for casting, in which all casting parameters were fully monitored. The pouring temperature was at $50^{\circ} \mathrm{C}$ above the liquidus of the alloy, according to the equilibrium phase diagram and measured by a K-type thermocouple. Six ASTM standard samples, i.e., three $\phi 6.35 \mathrm{~mm}$ round bars and three square bars, were cast in each shot. The diagram of die castings for the standard tensile testing samples is shown in Fig. 1 . The casting die was pre-heated by the circulation of mineral oil at $250^{\circ} \mathrm{C}$. All castings were left to cool to ambient temperature after removal from the die and kept in an ambient condition for at least 24 hours before mechanical property test was conducted.

Tensile testing followed the ASTM B557 standard using an Instron 5500 Universal Electromechanical Testing System equipped with Bluehill software and a $\pm 50 \mathrm{kN}$ load cell. All the tests were performed at ambient temperature $\left(\sim 25^{\circ} \mathrm{C}\right)$. The gauge length of the extensometer was $25 \mathrm{~mm}$ and the rate of extension was $2 \mathrm{~mm} / \mathrm{min}$. The reported data was obtained from averaging the results of 10 to 15 samples of each cast condition.

The specimens for microstructural examination were cut from the middle of the $\phi 6.35 \mathrm{~mm}$ round tensile test bars. The microstructure was examined using a Zeiss optical microscope equipped with an AxioVision 4.3 Quantimet digital image analysis system, and a Zeiss SUPRA 35VP scanning electron microscope (SEM) equipped with EDX. The particle size and volume fraction of the solid phase were measured using the quantitative metallographic system of the optical microscope. The quantitative EDX analysis in SEM was performed at an accelerating voltage of $20 \mathrm{kV}$ on a polished sample, and the libraries of standard X-ray profiles for EDX were generated using pure elements. In situ spectroscopy calibration was performed in each session of the EDX quantification using pure copper. To minimise the influence from the interaction volume during the EDX quantification, five analyses on selected particles were conducted for each phase and the average was taken as the reported measurement.

\section{Results}

\subsection{As-cast microstructure of the die-cast Al-Mg-Si-Mn alloy}

The typical microstructure of the die-cast Al-Mg-Si-Mn alloy is shown in Fig. 2. As previously described in terms of the characteristics and the formation of the microstructure of the die-cast Al-Mg-Si-Mn alloy [23], the two-stage solidification was responsible for the microstructural formation in high pressure die casting. The $\alpha$-Al phase formed in the shot sleeve has dendritic or fragmented dendritic morphology, whilst the $\alpha$-Al phase formed in the die cavity exhibited fine globular morphology. The interdendritic regions were characterised by the lamellar structure made of $\alpha$ - $\mathrm{Al}$ and $\mathrm{Mg}_{2} \mathrm{Si}$ eutectic phases. Fe-rich intermetallic compounds were observed in the eutectic areas and were identified as $\mathrm{Al}_{12}(\mathrm{Fe}, \mathrm{Mn})_{3} \mathrm{Si}$ [21]. There were no Ni-rich phases detected in the Al-Mg-Si-Mn alloy containing $0.005 \mathrm{wt} . \% \mathrm{Ni}$. This indicated that a very low Ni would not affect the microstructure and not result in the formation of any Ni-rich intermetallics in the alloy.

\subsection{Effect of $\mathrm{Ni}$ on the as-cast microstructure of the die-cast Al-Mg-Si-Mn alloy}

The effect of $\mathrm{Ni}$ on the as-cast microstructure of the die-cast Al-Mg-Si-Mn alloy is shown in Figs. 3 to 6. Generally, the increase of $\mathrm{Ni}$ results in the formation of more intermetallics in the as-cast microstructure (Fig. 3). Most of the intermetallics exhibited dendritic morphology, although some compact intermetallics were also observed when Ni content was up to 1.11 wt.\% (Fig. 4a,b\&c). Two types of intermetallics were observed as shown in Fig. 4d. One was in the typical dendritic morphology and the other was not clear at low magnification. The high magnification micrographs shown in Fig. 5 are taken from the alloy containing $2.06 \mathrm{wt} . \% \mathrm{Ni}$, where the typical laminar and dendritic intermetallic phases were seen at the grain boundaries and in the $\mathrm{Al}-\mathrm{Mg}_{2} \mathrm{Si}$ eutectic areas. The co-existence of the Al- $\mathrm{Mg}_{2} \mathrm{Si}$ eutectics and $\mathrm{Al}$ with Ni-rich intermetallic eutectics indicated that two eutectic solidifications occurred during casting. Fig. 6 shows that the solid fraction and the average size of the Ni-rich intermetallics in the as-cast microstructure were increased with increasing Ni contents in the alloy.

In comparison with the micrographs in Fig. 2, it is seen that the $\mathrm{Al}-\mathrm{Mg}_{2} \mathrm{Si}$ eutectic spacing increased in the microstructure obtained in the alloys with a higher Ni content, as shown in Fig. 3. The measured eutectic spacing of the Al- $\mathrm{Mg}_{2} \mathrm{Si}$ eutectic phase is summarised in Table 2. The average eutectic spacing of the eutectic Al phase was $0.41 \mu \mathrm{m}$ for the alloy without $\mathrm{Ni}$, but it increased to $0.58 \mu \mathrm{m}$ when $\mathrm{Ni}$ was raised to $2.06 \mathrm{wt}$.\%. According to the data summarised in ref. [21] for the $\mathrm{Al}-\mathrm{Mg}_{2} \mathrm{Si}$ eutectic reaction in similar alloys, the $\lambda^{2} \mathrm{~V}=15 \mu \mathrm{m}^{3} / \mathrm{s}$ can be used to estimate the relevant growth velocity. The calculated results are also given in Table 2. A significant reduction in the growth velocity of the eutectic can be seen with increasing Ni contents. This indicates that the eutectic solidification between $\mathrm{Al}$ and AlFeMnSiNi intermetallics might have occurred prior to or at the same 
temperature as the eutectic solidification of $\mathrm{Al}-\mathrm{Mg}_{2} \mathrm{Si}$, during which the release of latent heat during $\mathrm{Al}$ and intermetallics eutectic solidification could offer the resources to influence the solidification between $\mathrm{Al}$ and $\mathrm{Mg}_{2} \mathrm{Si}$.

As shown in Figs. 2 to 5, the dendritic Ni-rich intermetallics were usually associated with the primary $\alpha$-Al phase. SEM/EDX quantification identified that the dendritic Ni-rich intermetallics were of the typical composition of $\mathrm{Al}_{[100-140]}(\mathrm{Fe}, \mathrm{Mn})_{[2-7]} \mathrm{SiNi}_{[4-9]}$, as shown in Table 3. Meanwhile, the eutectic Ni-rich intermetallics were usually associated with $\mathrm{Al}-\mathrm{Mg}_{2} \mathrm{Si}$ eutectic phase and segregated at the primary $\alpha$-Al grain boundaries. The eutectic Ni-rich intermetallics were identified by EDX as the same AlFeMnSiNi phase with the typical composition of $\mathrm{Al}_{135}(\mathrm{Fe}, \mathrm{Mn})_{2} \mathrm{SiNi}_{9}$, as shown in Table 3 . It is clearly seen that (1) the Ni-rich intermetallics essentially consisted of $\mathrm{Fe}, \mathrm{Mn}$ and $\mathrm{Si}$, and no $\mathrm{Al}_{3} \mathrm{Ni}$ phase was detected in the studied alloy with $\mathrm{Ni}$ content up to 2.06 wt.\%; and (2) two types of Ni-rich intermetallics had the same constituent composition and could be described by the same chemical formula. It is noticeable that the Ni-rich intermetallic phase formed in the alloy was different to the intermetallic phases observed in other Al-Si-Mg alloys [18]. Song et al. found that $\mathrm{Al}_{3} \mathrm{Ni}$ were formed in the alloys with 1.4 wt.\% Ni. However, this binary intermetallic was not observed in our experimental alloy with an even higher Ni content. In order to further confirm the intermediate phase, a series of experiments were performed to find out the differences in XRD spectrums and the results are shown in Fig. 7. The peaks for $\alpha-\mathrm{Al}$ and $\mathrm{Mg}_{2} \mathrm{Si}$ phases were easily identified from the experimental results. However, it was difficult to find out the corresponding peaks of the AlFeMnSiNi intermetallics. Although some peaks were identified for $\alpha$ AlFeMnSi, several peaks were unable to be clearly identified with the existing database. However, the peaks were certainly not from $\mathrm{Al}_{3} \mathrm{Ni}$. The results confirmed the existence of new phases in the alloy. However, it is not able to confirm the existence of AlFeMnSiNi phase because of the insufficient information from the existing XRD database.

On the other hand, the formation sequence of intermetallics can be indirectly confirmed by analysing the distribution of solute elements in the primary phase and the eutectic phases. Fig. 8 shows the elements mapping of the primary intermetallics and eutectic intermetallics in the experimental alloy. In the backscattered SEM micrograph shown in Fig. 8a, the difference of the eutectic intermetallics in the middle and the primary intermetallics at the side was clear by their morphologies. The colour was essentially no different in the intermetallics, indicating that the distributions of different solute elements were uniform in the whole intermetallics. This clarified that $\mathrm{Ni}$ was dissolved into the intermetallics, rather than the affiliation on the surface of the Ferich intermetallics. This indicated that the Ni was associated with $\mathrm{Al}, \mathrm{Fe}, \mathrm{Mn}$ and $\mathrm{Si}$ from the beginning of solidification and Ni did not form other intermetallics first and then attach to the existing AlFeMnSi phase.

\subsection{Mechanical Properties}

Mechanical properties of the die-cast Al-Mg-Si-Mn alloy with different Ni contents are presented in Fig. 9. It is seen that there is a slight enhancement in the yield strength and a significant reduction of the elongation with the increase of the Ni content in the alloys. However, no obvious variation in ultimate tensile strength (UTS) was observed, although a slight increase of UTS was found when $\mathrm{Ni}$ was added at a low level. It is worth emphasising that the enhancement of the yield strength for the die-cast samples is less significant than the reduction of elongation in the same alloy in the experimental ranges. The overall increase of the yield strength of the die-cast sample was $10 \%$ while the elongation decreased by $350 \%$.

\subsection{CALPHAD modelling of the multi-component Al-Mg-Si-Mn-Fe-Ni system}

In order to understand the effect of alloying elements on the solidification and microstructural evolution, CALPHAD modelling of the multi-component Al-Mg-Si-Mn-Fe-Ni system was carried out using PandaT software [24]. The other low levels of elements were not considered. The calculated cross section of the equilibrium phase diagram of the Al-5Mg- $2 \mathrm{Si}-0.6 \mathrm{Mn}-0.2 \mathrm{Fe}-\mathrm{xNi}$ alloy is shown in Fig. 10, which could be divided into several regions with different Ni contents. The phase formation followed: (1) $\mathrm{L} \rightarrow$ $\alpha-\mathrm{Al}+\mathrm{Mg}_{2} \mathrm{Si}+\mathrm{Al}_{15}(\mathrm{Fe}, \mathrm{Mn})_{3} \mathrm{Si}_{2}$ with prior $\alpha-\mathrm{Al}$ phase at $\mathrm{Ni}<\left(0.05\right.$ wt. \%), (2) $\mathrm{L} \rightarrow \alpha-\mathrm{Al}+\mathrm{Mg}_{2} \mathrm{Si}+\mathrm{Al}_{15}(\mathrm{Fe}, \mathrm{Mn})_{3} \mathrm{Si} i_{2}$ with prior $\alpha-$ $\mathrm{Al}_{15}(\mathrm{Fe}, \mathrm{Mn})_{3} \mathrm{Si}_{2}$ phase at $0.05 \mathrm{wt} . \%<\mathrm{Ni}<0.15 \mathrm{wt} . \%$, and (3) $\mathrm{L} \rightarrow \alpha-\mathrm{Al}+\mathrm{Mg}_{2} \mathrm{Si}+\mathrm{Al}_{15}(\mathrm{Fe}, \mathrm{Mn})_{3} \mathrm{Si}_{2}+\mathrm{Al}_{3} \mathrm{Ni}$ with prior $\alpha-\mathrm{AlFeMnSi}$ and $\alpha-\mathrm{Al}$ phase at $0.15 \mathrm{wt} . \%<\mathrm{Ni}<4 \mathrm{wt} . \%$ (4 wt.\% was the calculated limits in Fig. 9, the actual limit should be different). It needs to be emphasised that the phase formation for the intermetallics according to the equilibrium phase diagram was different from the ascast microstructure of the experimental alloys with varied contents of Ni. The difference was attributed to several factors; including the non-equilibrium solidification in high pressure die-casting process, the complex precipitation process of intermetallics during solidification, and the limitation of the database used in the phase diagram calculation. However, the equilibrium phase diagram had provided useful information for the solidification process.

The solidification process of the alloy with different contents of $\mathrm{Ni}$ is shown in Fig. 11. It is seen that there is an increase of the solid phase and a decrease of the liquid phase at a given temperature between liquidus and solidus for the alloy with increased Ni content. The results are shown in Fig. 11a for the alloy containing $0.005 \mathrm{wt} . \% \mathrm{Ni}$, where no Ni-rich intermetallic phase was found in the solidification curve. This was consistent with the experimental results given in Fig 2. In Fig. $10 \mathrm{~b}$, the alloy with 2.06 wt. $\%$ Ni showed different solidification features: (a) The liquidus temperature was almost the same for two alloys; (b) The primary $\alpha$-Al phase emerged at $621^{\circ} \mathrm{C}$ in Fig. $10 \mathrm{a}$ but $614^{\circ} \mathrm{C}$ in Fig. $10 \mathrm{~b}$; (c) The eutectic temperature was $584^{\circ} \mathrm{C}$ in Fig. $11 \mathrm{a}$ and $575^{\circ} \mathrm{C}$ in Fig. $10 \mathrm{~b}$; and (d) The most interesting point was that the emergence of Ni-rich intermetallics was prior to the eutectic solidification of $\mathrm{Al}-\mathrm{Mg}_{2} \mathrm{Si}$. In the meantime, the eutectic reactions for $\mathrm{Al}-\mathrm{Mg}_{2} \mathrm{Si}$ and $\mathrm{Al}-\mathrm{AlFeMnSiNi}$ were at the same temperature. The results confirmed that the increase of $\mathrm{Ni}$ in the alloy resulted in an increase of the solidification range of the alloy, therefore increasing the possibility of forming hot tearing and shrinkage porosity in the casting.

\section{Discussion}

\subsection{Phase formation in die-cast Al-Mg-Si-Mn alloy with $\mathrm{Ni}$}

The experimental observations have confirmed that (1) the primary AlFeMnSiNi intermetallics were formed as prior phase during high pressure die-casting, which showed dendritic and fragmented dendritic morphology with different sizes; (2) the eutectics included $\mathrm{Al}-\mathrm{Mg}_{2} \mathrm{Si}$ and $\mathrm{Al}-\mathrm{AlFeMnSiNi}$, but no $\mathrm{Al}_{3} \mathrm{Ni}$ intermetallics were observed in the $\mathrm{Al}-\mathrm{Mg}-\mathrm{Si}-\mathrm{Mn}$ die-cast alloys with varied $\mathrm{Ni}$ contents up to $2.06 \mathrm{wt} . \%$. 
J Mater Sci (2014) 49:8412-8422

Generally, the phase formation of Ni-rich intermetallics in the experimental alloys is broadly consistent with the equilibrium phase diagram calculated from CALPHAD. Therefore the solidification path can be used to explain the major features of the microstructure if $\alpha$-AlFeMnSi and $\mathrm{Al}_{3} \mathrm{Ni}$ are taken as the same phase from the primary solidification and eutectic solidification. The solidification process and the associated changes of liquid compositions determine the formation of different phases. From the phase diagram in Fig. 10, the prior phase is $\alpha$-Al phase when Ni content is less than $0.05 w t . \%$. The solidification starts with the formation of the $\alpha-\mathrm{Al}$ phase, followed by the formation of $\mathrm{AlFeMnSi}$ and eutectics of $\mathrm{Al}-\mathrm{Mg}_{2} \mathrm{Si}$. This has been discussed in previous publications $[21,22]$. When $\mathrm{Ni}$ content is increased to a higher level, the prior phase becomes the AlFeMnSiNi phase. The precipitation of AlFeMnSiNi compounds decreases the undercooling in front of the interface of the crystal, resulting in the nucleation and growth of $\alpha$-Al phase in association with AlFeMnSiNi compounds (Figs. 3\&4). The solidification continues until the completion of eutectic solidification. When Ni content is further increased, the prior phase is still AlFeMnSiNi phase, but the primary solidification cannot consume all of the $\mathrm{Ni}$ in the alloy and therefore $\mathrm{Ni}$ takes part in the eutectic solidification to form Al$\mathrm{AlFeMnSiNi}$ eutectics in association with $\mathrm{Al}-\mathrm{Mg}_{2} \mathrm{Si}$ eutectics. Overall, $\mathrm{Ni}$ in the Al-Mg-Si-Mn alloy is consumed by forming primary AlFeMnSiNi phase in the primary solidification and Al- AlFeMnSiNi eutectics in the eutectic solidification, which is always associated with the consumption of $\mathrm{Fe}, \mathrm{Mn}$ and $\mathrm{Si}$. On the other hand, the addition of $\mathrm{Ni}$ in the alloy introduces new prior phase that releases latent heat during solidification. Therefore, the cooling rate for $\mathrm{Al}-\mathrm{Mg}_{2} \mathrm{Si}$ eutectic solidification is reduced, resulting in the increase of the eutectic spacing.

The absence of $\mathrm{Al}_{3} \mathrm{Ni}$ intermetallics in the die-cast $\mathrm{Al}-\mathrm{Mg}-\mathrm{Si}-\mathrm{Mn}$ alloy is one important feature. In the equilibrium state, $\mathrm{Al}_{3} \mathrm{Ni}$ phase that contains $42 \mathrm{wt} . \% \mathrm{Ni}$ has an orthorhombic structure (the space group Pnma, 16 atoms in the unit cell) with the lattice parameters $a=0.6611 \mathrm{~nm}, \mathrm{~b}=0.73662 \mathrm{~nm}$, and $\mathrm{c}=0.4812 \mathrm{~nm}$. The heat of forming this phase is $40 \mathrm{~J} / \mathrm{mol}$. The density of the phase in the binary system is in the range $3.95-3.96 \mathrm{~g} / \mathrm{cm}^{3}$ [25]. Currently, it is not clear yet for the association between $\alpha$ $\mathrm{AlFeMnSi}$ and $\mathrm{Ni}$ in the experimental alloy. It was observed that $\mathrm{Al}_{3} \mathrm{Ni}$ were formed in a fairly low $\mathrm{Ni}$ content in $\mathrm{Al}-\mathrm{Mg}$-Si wrought alloys $[16,18]$, which is not consistent with the results in this work. However, the differences between previous work and this work is obvious because the Fe content is low in the wrought alloy and the Mn content is relatively high in the alloy in this work. The role of $\mathrm{Mn}$ in cast Al-Mg-Si-Mn alloy has been discussed in our previous works [22,26,27]. Although the association between $\mathrm{Ni}$ and $\mathrm{AlFeMnSi}$ intermetallics has been indirectly confirmed, the mechanism of the formation of $\mathrm{AlFeMnSiNi}$ intermetallics needs to be addressed as it may be important to the development of materials for special applications.

\subsection{Microstructure-property relationship}

The experimental results have confirmed that the addition of nickel significantly affects the mechanical properties of the Al-Mg$\mathrm{Si}-\mathrm{Mn}$ alloy. The higher the nickel content in the alloy, the more significant the reduction in ductility. This is accompanied by a slight enhancement of the yield strength at an increased nickel level in the alloy. The UTS increases slightly when a small amount of $\mathrm{Ni}$ is added to the die-cast alloys but further increase of the Ni content results in the decrease of the UTS.

Referring to the solidification microstructure, the enhanced yield strength is believed to correspond to the increased amounts of $\mathrm{Ni}$-rich intermetallic compounds presented at the $\alpha$ - $\mathrm{Al}$ grain boundaries and eutectic $\mathrm{Al}-\mathrm{Mg}_{2} \mathrm{Si}$ areas. The increase in the yield strength is accompanied with decreasing elongation as the added reinforcement due to the Ni-rich compounds is at the cost of the alloy ductility. Therefore the Ni content should be limited to a low level during alloy recycling in order to maintain the mechanical properties of the die-castings without significant loss in ductility.

\section{Conclusions}

1) In the die-cast $\mathrm{Al}-\mathrm{Mg}$-Si-Mn alloy containing different $\mathrm{Ni}$ content, the formation of Ni-rich intermetallics occurs consistently during solidification. The Ni-rich intermetallics exhibit dendritic and lamellar morphology during primary and eutectic solidification, respectively.

2) In the die-cast $\mathrm{Al}-\mathrm{Mg}$-Si-Mn alloy, $\mathrm{Ni}$ is always associated with $\mathrm{Fe}, \mathrm{Mn}$ and $\mathrm{Si}$ to form $\mathrm{AlFeMnSiNi}$ intermetallics. $\mathrm{No} \mathrm{Al}_{3} \mathrm{Ni}$ intermetallics is observed at $\mathrm{Ni}$ concentrations up to $2.06 \mathrm{wt} \%$, while both primary AlFeMnSiNi phase and eutectic $\mathrm{AlFeMnSiNi}$ phase are found in the as-cast microstructure. Both the primary and eutectic Ni-rich intermetallics are identified as the same $\mathrm{AlFeMnSiNi}$ phase with the typical composition of $\mathrm{Al}_{[100-140]}(\mathrm{Fe}, \mathrm{Mn})_{[2-7]} \mathrm{SiNi}_{[4-9]}$.

3) The increased Ni-rich intermetallics can be found in the alloy with higher Ni contents. The increased Ni contents result in an increase in the spacing of $\mathrm{Al}-\mathrm{Mg}_{2} \mathrm{Si}$ eutectics in the die-cast Al-Mg-Si-Mn alloy. This indicates that the increased levels of Ni contents lower the growth velocity of the eutectic $\mathrm{Al}-\mathrm{Mg}_{2} \mathrm{Si}$ during the solidification of the die-cast Al-Mg-Si-Mn alloy.

4) The addition of Ni significantly affects the mechanical properties of the alloy castings. The higher the Ni content in the alloy, the more significant the reduction in ductility. This is accompanied by a slight enhancement of the yield strength. The ultimate tensile strength increases slightly when adding a small amount of Ni into the die-cast alloys, but further increase of the Ni content results in the decrease of the UTS.

\section{Acknowledgement}

The authors acknowledge the Engineering and Physical Sciences Research Council (EPSRC), Technology Strategy Board (TSB) and Jaguar Land Rover (JLR) in United Kingdom for financial support.

\section{References}

[1] Boon JE, Isaacs JA, Gupta SM (2000) Economic impact of aluminium intensive vehicles on the US automotive. Recycling Infrastructure. J. Ind. Ecol. 4:117-134.

[2] Huang C-L, Vause J, Ma HW, Yu C-P (2012) Using material/substance flow analysis to support sustainable development assessment: A literature review and outlook. Resour. Conserv. Recycl. 68:104-116.

[ 3 ] European Aluminium Association (EAA) (2007) Aluminium in cars. http://www.alueurope.eu/pdf/Aluminium_in_cars_Sept2008.pdf, pp 1-20. 
[4] Kim HJ, Keoleian GA, Skerlos SJ (2011) Economic assessment of greenhouse gas emissions reduction by vehicle lightweighting using aluminium and high-strength steel. J. Ind. Ecol. 15:64-80.

[5] Dalmijn WL, De Jong TPR (2007) The development of vehicle recycling in Europe: sorting, shredding, and separation. JOM 59:52-56.

[6] European Aluminium Association \& Organisation of Aluminium Refiners and Remelters (EAA-OEA) (2008), Aluminium recycling in Europe - the road to high quality products. pp 1-51.

[7] Ciacci L, Morselli L, Passarini F, Santini A, Vassura I (2010) A comparison among different automotive shredder residue treatment processes. Int. J. Life Cycle Assess 15:896-906.

[8] Santini A, Morselli L, Passarini F, Vassura I, Di Carlo S, Bonino F (2011) End-of-life vehicles management: Italian material and energy recovery efficiency. Waste Management 31:489-494.

[9] Liu ZK (2003) Effect of impurities on alloys, I. T. Program. Washington, DC: Energy Efficiency and Renewable Energy, US Department of Energy.

[10] Liu L, Samuel FH (1997) Assessment of melt cleanliness in A356.2 aluminium casting alloy using the porous disc filtration apparatus technique. J. Mater. Sci. 32:5901-5925.

[11] Gaustad G, Olivetti E, Kirchain R (2010) Design for recycling. J. Ind. Ecology 14:286-308.

[12] Gaustad G, Olivetti E, Kirchain R (2012) Improving aluminium recycling: A survey of sorting and impurity removal technologies. Resources, Conservation and Recycling 58:79-87.

[ 13 ] Global Aluminium Recycling (2013) A cornerstone of sustainable development. http://www.worldaluminium.org/media/filer_public/2013/01/15/f10000181.pdf

[14] ASM Specialty Handbook (1993) Aluminium and aluminium alloys, J. R. Davis, Davis \& Associates Eds., ASM International, Materials Park, $\mathrm{OH}$.

[15] Barr CJ, McDonald DT, Xia K (2013) Significantly enhanced tensile strength and bronze by equal channel angular pressing and subsequent heat treatment. J. Mater. Sci. 48: 4749-4757.

[16] Zhu S, Yao J, Sweet L, Easton M, Taylor J, Robinson P, Parson P (2013) Influences of nickel and vanadium impurities on microstructure of aluminium alloys. JOM 65:584-592.

[17] Dan B, Georgeta C, Angel A (2006) Critical analysis of Al-Ni phase diagrams. Metalurgia International 11:36-45.

[18] Song JM, Lin TY, Chuang HY (2007) Microstructural characteristics and vibration fracture properties of Al-Mg-Si alloys with excess $\mathrm{Cu}$ and Ni. Mater. Trans. 48:854-862.

[19] Mallapur DG, Kori SA, Rajendra Udupa K (2011) Influence of Ti, B and Sr on the microstructure and mechanical properties of A356 alloy. J. Mater. Sci. 46:1622-1642.

[20] Ji S, Watson D, Fan Z, White M (2012) Development of a super ductile diecast Al-Mg-Si alloy. Mater. Sci. Eng. A. 556: 824-833.

[21] Ji S, Wang Y, Watson D, Fan Z (2013) Microstructural evolution and solidification behaviour of Al-Mg-Si alloy in highpressure die casting. Metall. Mater. Trans. A 44: 3185-3197.

[22] Ji S, Yang W, Gao F, Watson D, Fan Z (2013) Effect of iron on the microstructure and mechanical property of Al-Mg-Si$\mathrm{Mn}$ and $\mathrm{Al}-\mathrm{Mg}-\mathrm{Si}$ diecast alloys. Mater. Sci. Eng. A564:130-139.

[23] Yang H, Ji S, Watson D, Fan Z (2014) Microstructure and mechanical properties of ductile aluminium alloy manufactured by recycled materials. Materials Science Forum 794-796:1077-1082.

[24]Chen S-L, Zhang SDF, Chang YA, Yan XY, Xie FY, Schmid-Fetzef R, Oatesd WA (2002) The PANDAT software package and its applications. Calphad 26:175-188.

[25] Belov NA, Aksenov AA, Eskin DG, (2002) Iron in aluminium alloys: impurity and alloying element (Advances in Metallic Alloys), CRC Press, p23.

[26] Watson D, Ji S, Fan Z (2014) A super-ductile alloy for the diecasting of aluminium automotive body structural components. Materials Science Forum 794:526-531.

[27] Ji S, Wang W, Watson D, Fan Z (2014) Microstructural characteristics of diecast AlMgSiMn Alloy. Materials Science Forum 783: 234-239. 
Table 1 Compositions of the die-cast Al-Mg-Si-Mn alloy with different Ni contents used in experiments (wt.\%).

\begin{tabular}{llllllllll}
\hline Alloy & $\mathrm{Si}$ & $\mathrm{Mn}$ & $\mathrm{Mg}$ & $\mathrm{Ni}$ & $\mathrm{Ti}$ & $\mathrm{Fe}$ & Others & $\mathrm{Al}$ \\
\hline $\mathrm{A}$ & 2.01 & 0.58 & 5.31 & 0.005 & 0.15 & 0.11 & $<0.03$ & bal. \\
$\mathrm{B}$ & 1.99 & 0.54 & 5.32 & 0.16 & 0.16 & 0.09 & $<0.03$ & bal. \\
$\mathrm{C}$ & 1.97 & 0.51 & 5.36 & 0.57 & 0.14 & 0.08 & $<0.03$ & bal. \\
$\mathrm{D}$ & 1.98 & 0.53 & 5.38 & 1.11 & 0.16 & 0.09 & $<0.03$ & bal. \\
$\mathrm{E}$ & 1.92 & 0.51 & 5.33 & 2.06 & 0.15 & 0.09 & $<0.03$ & bal. \\
\hline
\end{tabular}

Table 2 The average eutectic spacing of the eutectic Al phase in the Al-Mg-Si-Mn alloys with different levels of Ni.

\begin{tabular}{llll}
\hline $\mathrm{Ni}($ wt.\%) & $\begin{array}{l}\mathrm{Al}-\mathrm{Mg}_{2} \mathrm{Si} \text { eutectic } \\
\text { lamellae }(\mu \mathrm{m})\end{array}$ & spacing between & $\begin{array}{l}\mathrm{Al} \\
\left.\mathrm{Calculated} \text { growth velocity according to } \lambda^{2} \mathrm{~V}=15 \mathrm{~m} / \mathrm{s}\right)[21]\end{array}$ \\
\hline 0.005 & 0.41 & 89.23 \\
0.16 & 0.43 & 81.12 \\
0.57 & 0.47 & 67.90 \\
1.11 & 0.52 & 55.47 \\
2.06 & 0.58 & 44.59 \\
\hline
\end{tabular}

Table 3 Average compositions of Fe-rich intermetallic phases measured by quantitative SEM/EDX analysis in the die-cast $\mathrm{Al}-\mathrm{Mg}-\mathrm{Si}-\mathrm{Mn}$ alloys used in experiments.

\begin{tabular}{llllllll}
\hline $\begin{array}{l}\mathrm{Ni} \\
(\text { wt.\% })\end{array}$ & Phase morphology & Identified compounds & $\begin{array}{l}\mathrm{Al} \\
(\text { at.\% })\end{array}$ & $\begin{array}{l}\mathrm{Si} \\
\text { (at.\%) }\end{array}$ & $\begin{array}{l}\mathrm{Mn} \\
\text { (at.\%) }\end{array}$ & $\begin{array}{l}\mathrm{Fe} \\
\text { (at.\%) }\end{array}$ & $\begin{array}{l}\mathrm{Ni} \\
\text { (at.\%) }\end{array}$ \\
\hline 0.005 & irregular compact & $\mathrm{Al}_{12}(\mathrm{Fe}, \mathrm{Mn})_{3} \mathrm{Si}$ & 75.47 & 6.09 & 6.28 & 12.16 & 0 \\
0.16 & fine dendrites & $\mathrm{Al}_{106}(\mathrm{Fe}, \mathrm{Mn})_{7} \mathrm{SiNi}_{4}$ & 91.22 & 0.71 & 2.69 & 2.36 & 3.02 \\
0.57 & fine dendrites & $\mathrm{Al}_{132}(\mathrm{Fe}, \mathrm{Mn})_{5} \mathrm{SiNi}_{7}$ & 92.8 & 0.57 & 1.33 & 1.52 & 3.78 \\
1.11 & fine dendrites & $\mathrm{Al}_{154}(\mathrm{Fe}, \mathrm{Mn})_{3} \mathrm{SiNi}_{8}$ & 94.32 & 0.49 & 0.79 & 0.71 & 3.69 \\
2.06 & fine dendrites & $\mathrm{Al}_{147}(\mathrm{Fe}, \mathrm{Mn})_{2} \mathrm{SiNi}_{9}$ & 94.14 & 0.51 & 0.61 & 0.37 & 4.37 \\
& Eutectic needles & $\mathrm{Al}_{135}(\mathrm{Fe}, \mathrm{Mn})_{2} \mathrm{SiNi}_{9}$ & 93.26 & 0.56 & 0.62 & 0.45 & 5.11 \\
\hline
\end{tabular}




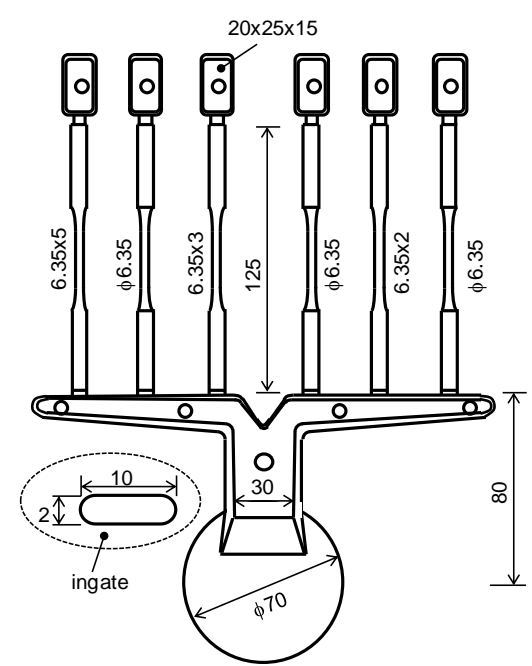

Figure 1 Diagram of die castings for the standard tensile testing samples of the Al-Mg-Si-Mn alloys according to the specification defined in ASTM B557-06. The overflow and biscuit are designed in association with the cold chamber die casting machine. The dimensions are in $\mathrm{mm}$.
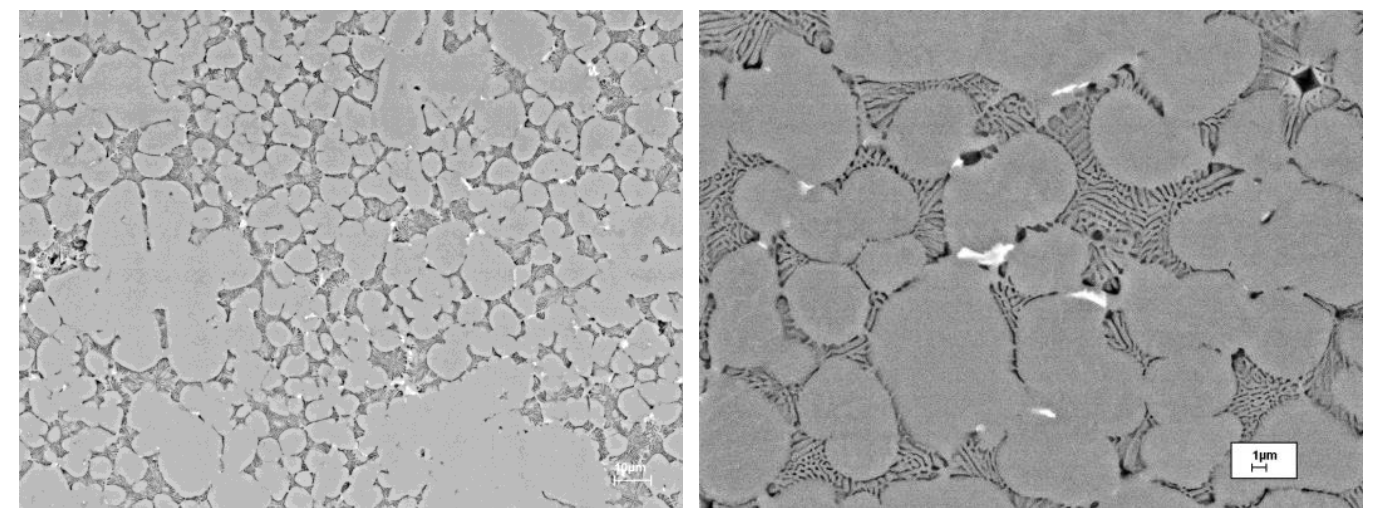

Figure 2 SEM images showing (a) the morphology of primary $\alpha$-Al phase and (b) the morphology of eutectics and intermetallics in the Al-Mg-Si-Mn alloy without Ni addition.
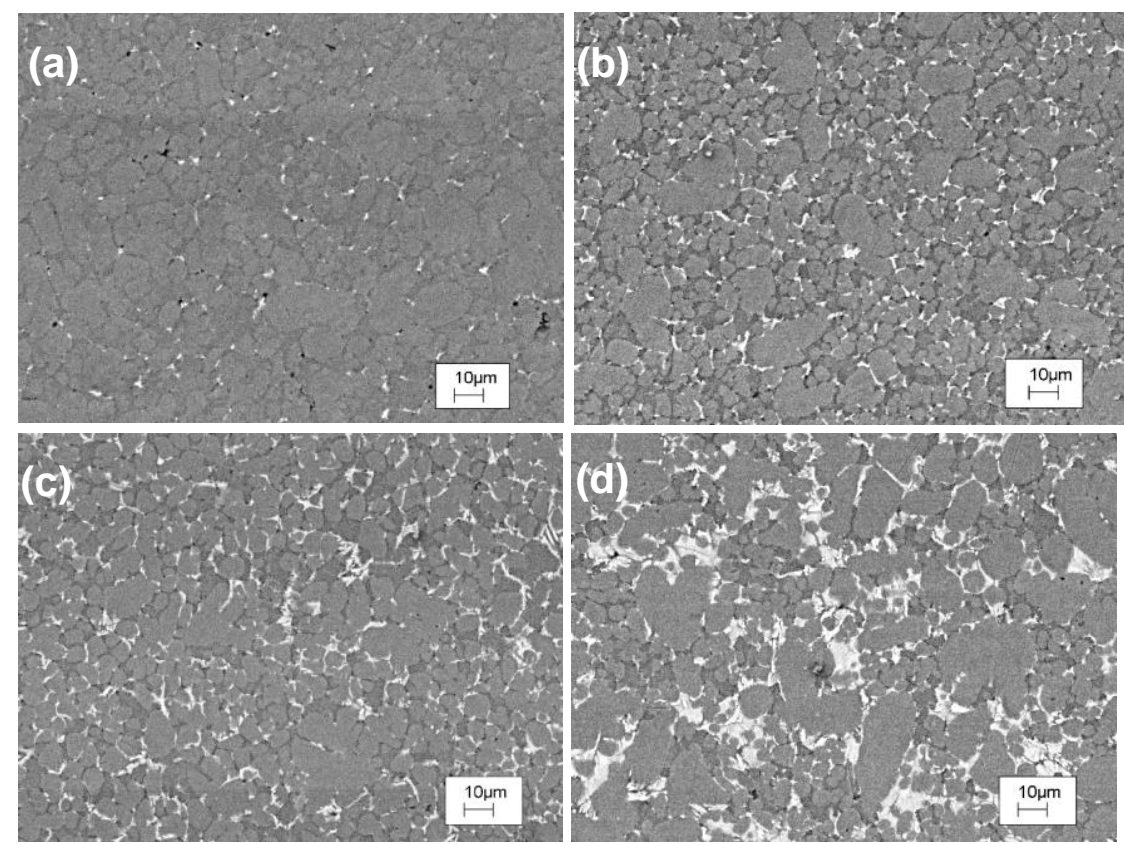

Figure 3 Backscattered SEM micrographs showing the morphology of Ni-rich intermetallics in the die-cast AlMg-Si-Mn alloys with different levels of Ni, (a) 0.16 wt. $\%$ Ni, (b) 0.57 wt. $\%$ Ni, (c) 1.11 wt.\% Ni, (d) 2.06 wt.\% $\mathrm{Ni}$. 


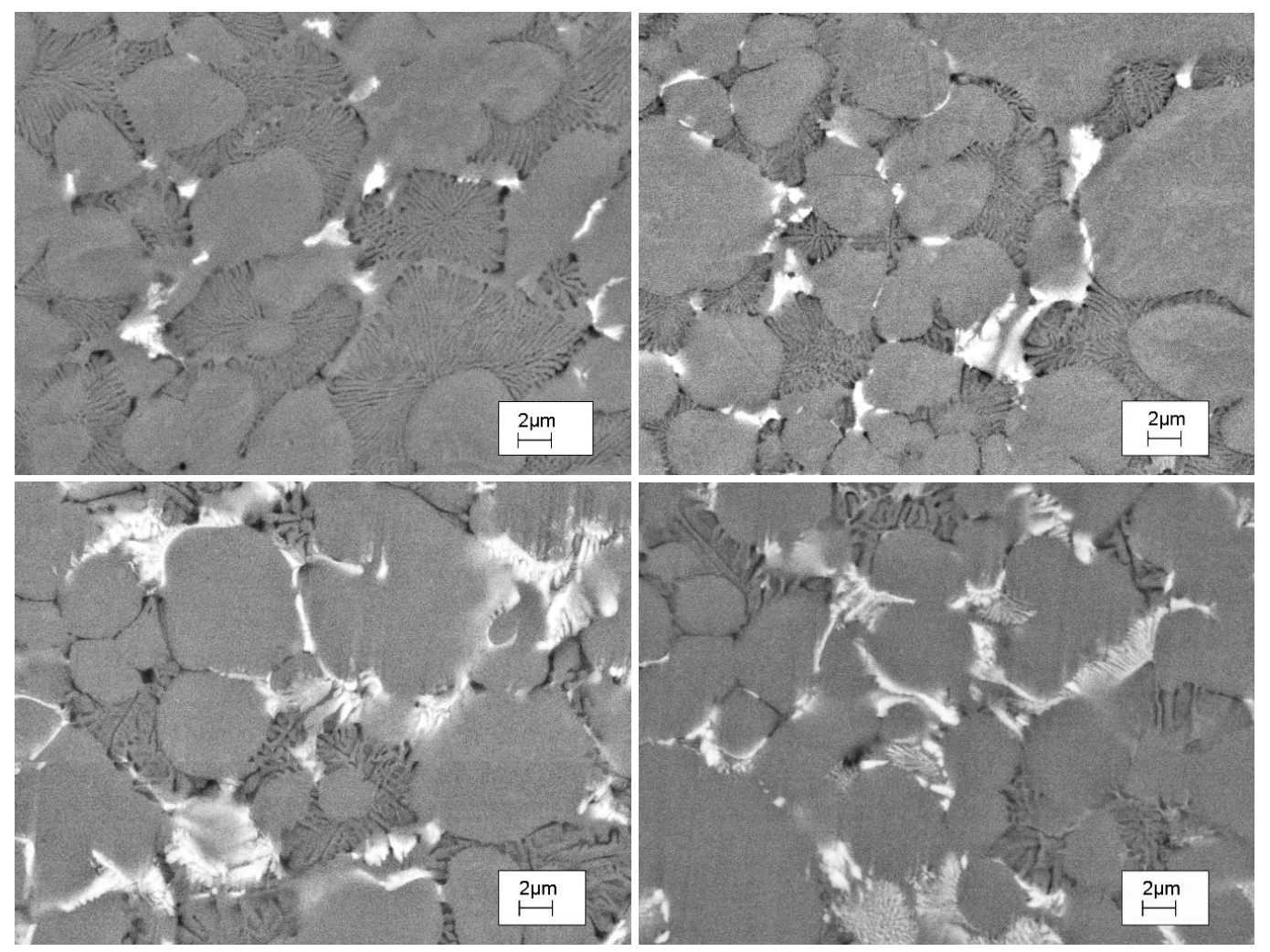

Figure 4 Backscattered SEM micrographs showing the morphology of Ni-rich intermetallics in the die-cast AlMg-Si-Mn alloys with different levels of Ni, (a) 0.16 wt.\% Ni, (b) 0.57 wt.\% Ni, (c) 1.11 wt.\% Ni, (d) 2.06 wt.\% Ni.

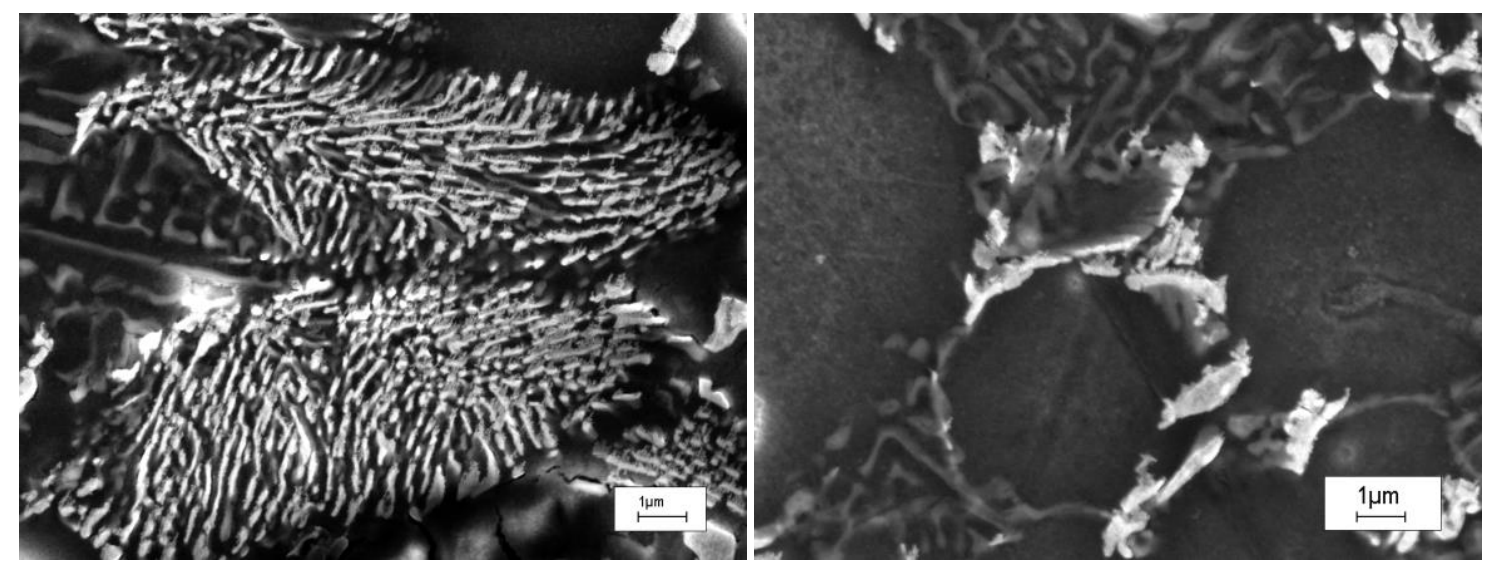

Figure 5 Inlens SEM images showing the morphology of (a) ternary eutectic structure and (b) dendritic Ni-rich primary phase in the Al-Mg-Si-Mn alloy with 2.06 wt.\% Ni. 

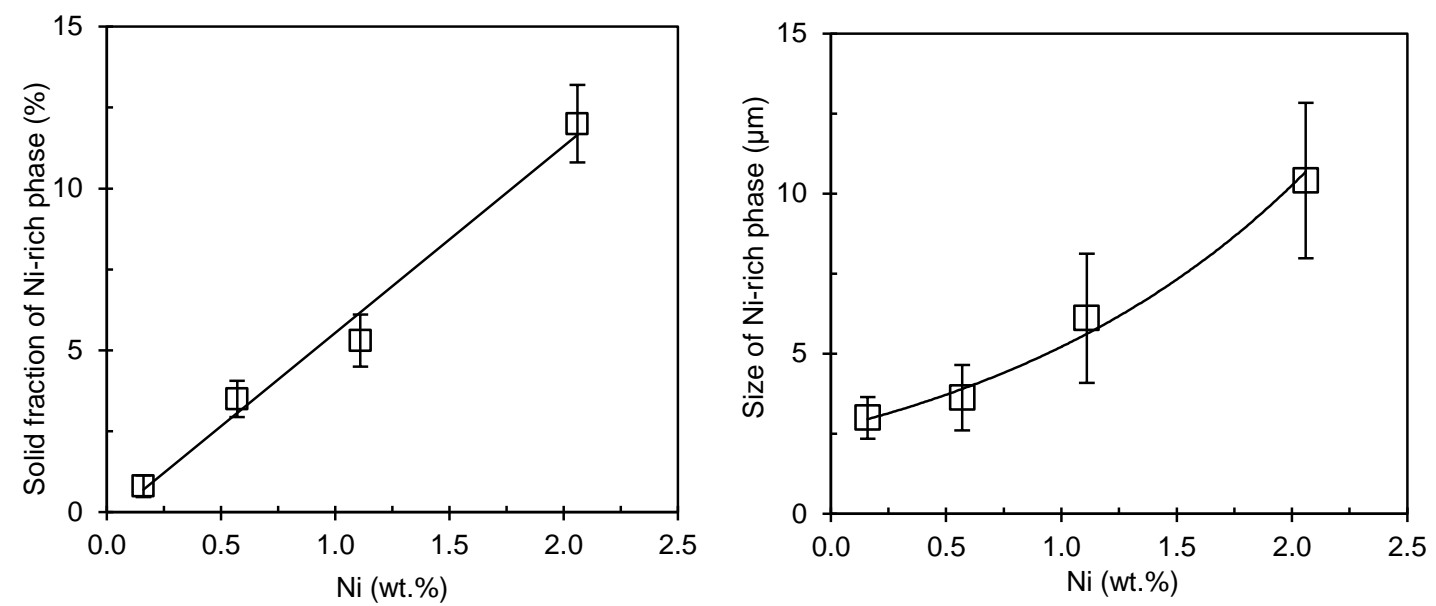

Figure 6 Effect of $\mathrm{Ni}$ content in the die-cast Al-Mg-Si-Mn alloy on (a) the volume fraction and (b) the average size of Ni-rich intermetallic phase.

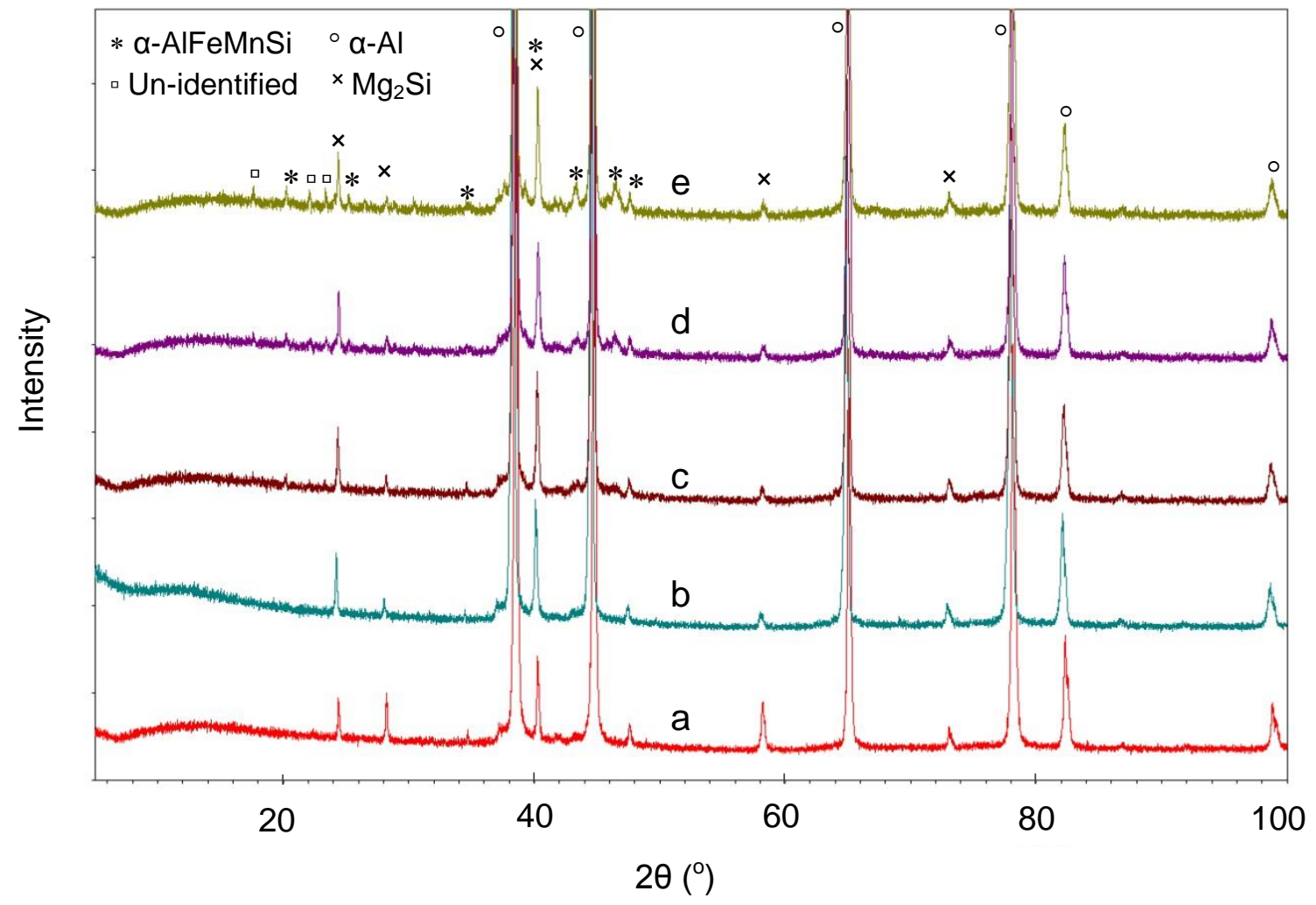

Figure 7 XRD spectrums of the Al-Mg-Si-Mn alloys with different levels of Ni, (a) 0.005 wt.\% Ni, (b) 0.16 wt.\% $\mathrm{Ni}$, (c) 0.57 wt.\% Ni, (d) 1.11 wt.\% Ni, (e) 2.06 wt.\% Ni. 


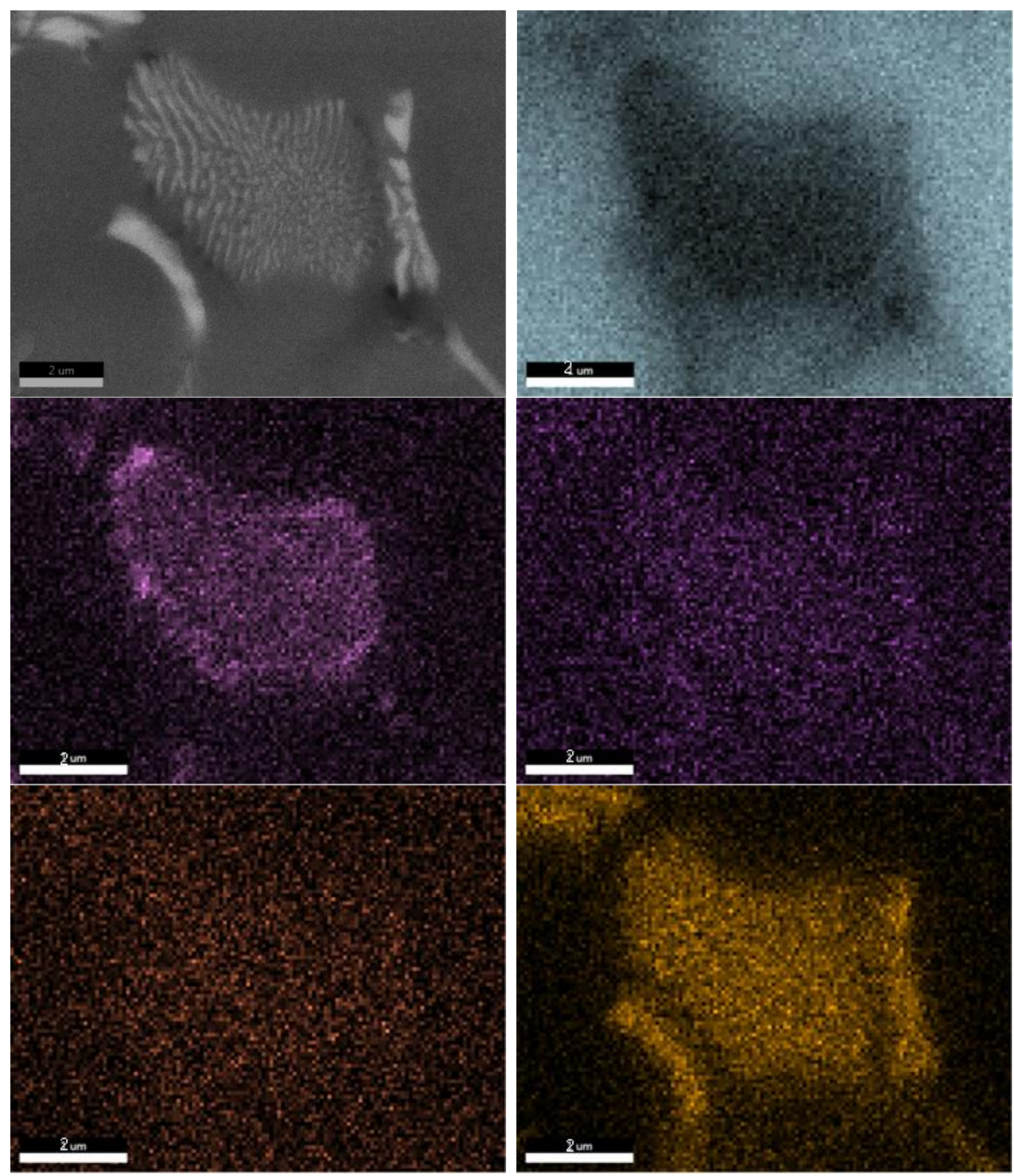

Figure 8. Backscattered SEM micrograph and the series of elemental maps showing the distribution of key elements in the intermetallics of the Al-Mg-Si-Mn die-cast alloy. Map conditions: $20 \mathrm{kV}, 185 \mathrm{nA}, 5 \mathrm{~nm}$ step size and a counting time of $15 \mathrm{~ms}$ per step. 


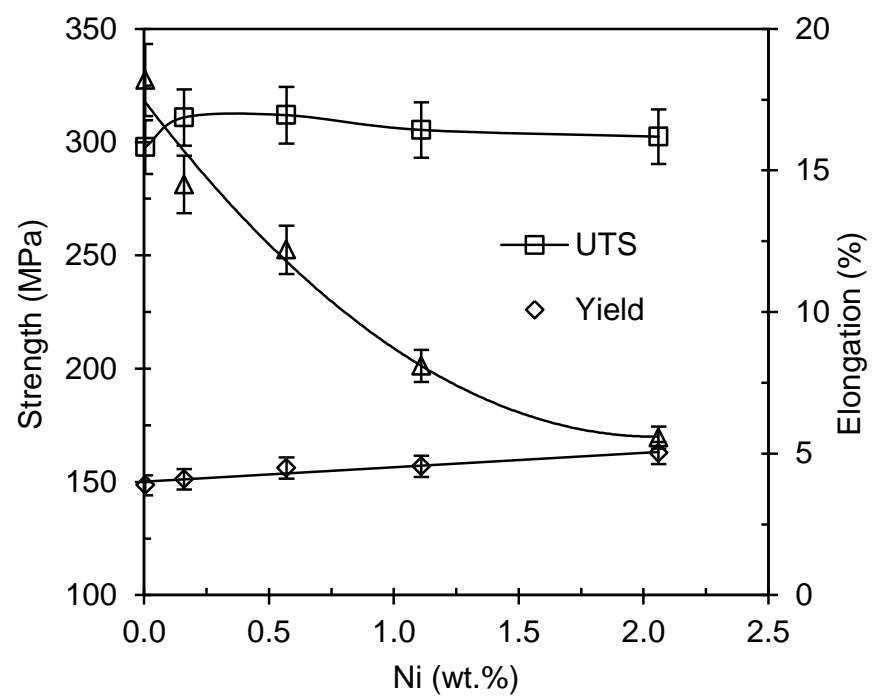

Figure 9 Effect of Ni content on the mechanical properties of the die-cast Al-Mg-Si-Mn alloy.

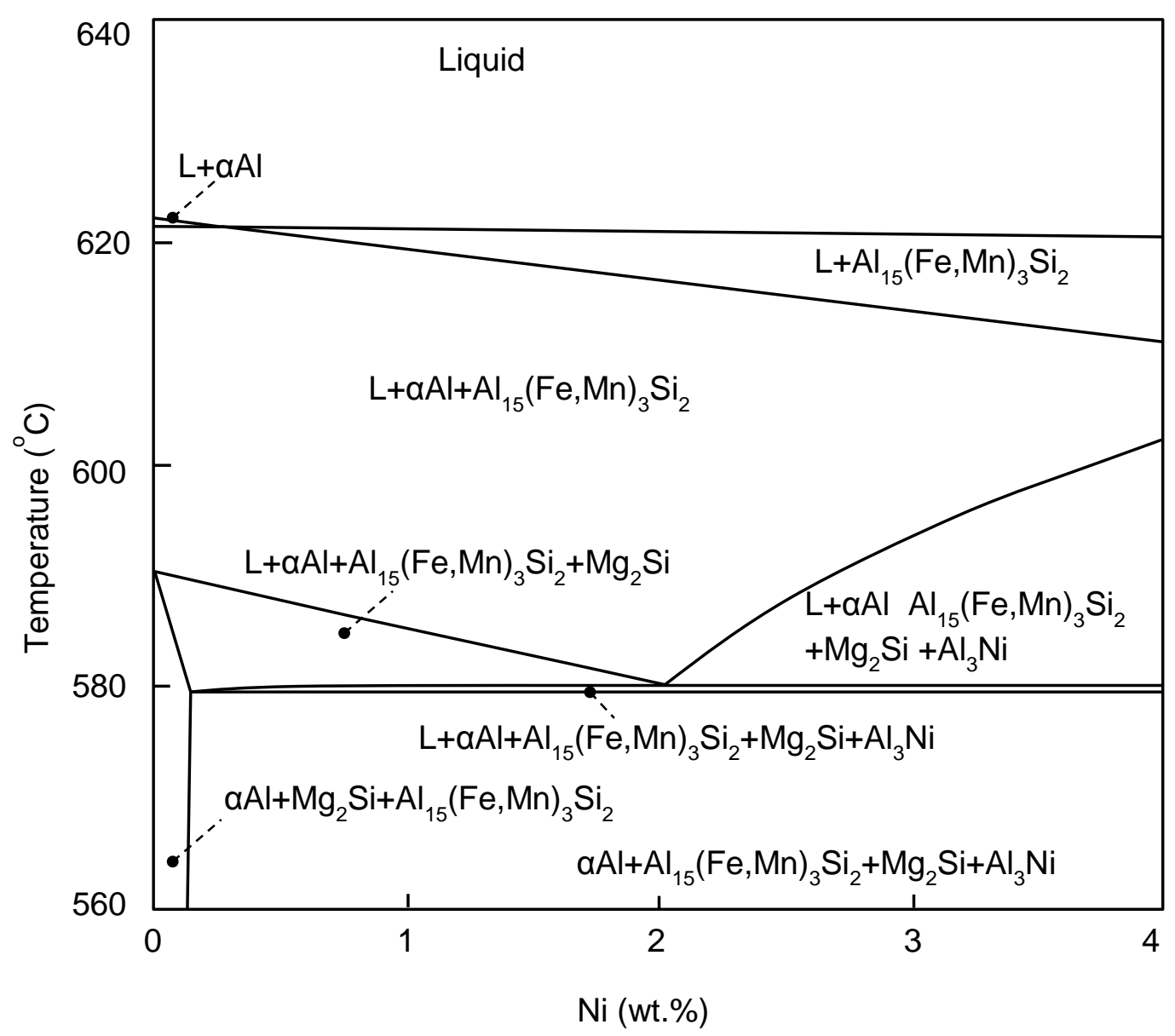

Figure 10 Equilibrium phase diagram of the Al-5Mg-2Si-0.6Mn- $0.2 \mathrm{Fe}-\mathrm{xNi}$ alloy calculated with Pandat software. 

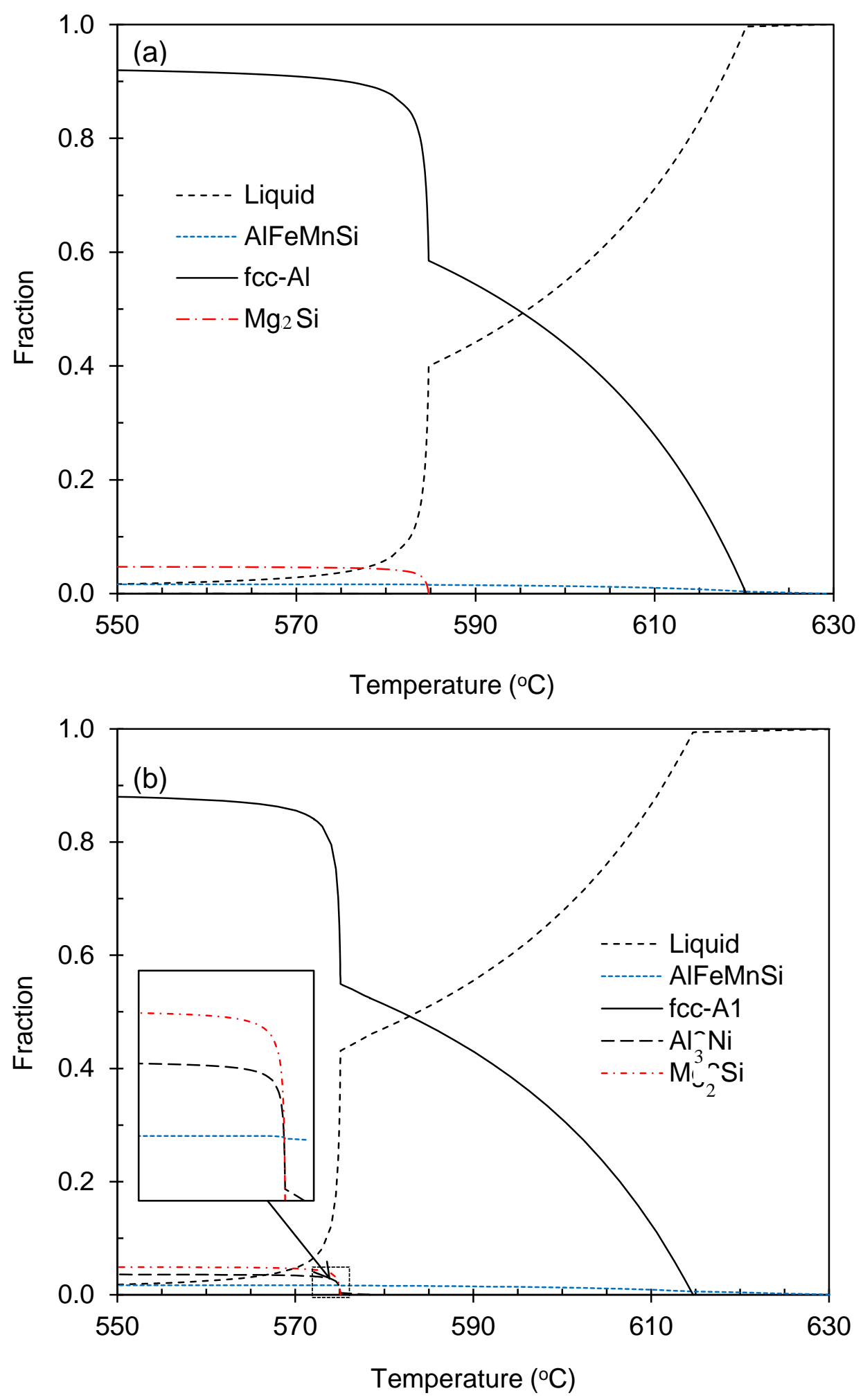

Figure 11 The variation of the fraction of the liquid phase and solidified phases with temperature in the solidification interval of the Al-Mg-Si-Mn alloys with (a) 0.005 wt.\% Ni, (b) 2.06 wt.\% Ni. 